\title{
Serum S100B protein: a useful marker in obstructive sleep apnea syndrome
}

\section{Stężenie biatka S100B w surowicy jako przydatny wskaźnik w zespole obłuracyjnego bezdechu podczas snu}

\author{
Serap Duru', Ibrahim Hikmet Firat', Nujen Colak², Zeynep Ginişs, Tuncay Delibaşı', Sadık Ardıç' \\ IClinic of Chest Disease, Dışkapı Yıldırım Beyazıt Training and Research Hospital, Ankara, Turkey \\ 2 Clinic of Endocrinology, Dışkapı Yıldırım Beyazit Training and Research Hospital, Ankara, Turkey \\ ${ }^{3}$ Department of Biochemistry, Dişkapı Yildrrım Beyazı Training and Research Hospital, Ankara, Turkey
}

Neurologia i Neurochirurgia Polska 2012; 46, 5: 450-455

DOI: 10.5114/ninp.2012.31355

\begin{abstract}
Background and purpose: We aimed to underline the importance of serum S100B protein as a useful biochemical marker in patients with obstructive sleep apnea syndrome (OSAS). Material and methods: Forty-three newly diagnosed patients with OSAS (median apnea-hypopnea index [AHI, events/ hour]: 37.5 [range 11.3-137]) and 25 subjects with AHI $<5$ (median AHI: 4.4 [range 0.7-4.8]) were included in the study. Serum $\mathrm{S} 100 \mathrm{~B}$ protein level was tested in serum samples taken after polysomnography in both groups and the difference between OSAS patients and the control group regarding that level was assessed. In addition, the association of $\mathrm{S} 100 \mathrm{~B}$ protein serum level with age, body mass index, AHI, mean $\mathrm{O}_{2}$ saturation percentage during sleep, minimum $\mathrm{O}_{2}$ saturation value (\%) at the end of the apneas, and the time spent at an $\mathrm{O}_{2}$ saturation less than $90 \%$ were analyzed in the OSAS patient group.

Results: Median serum S100B protein level was $133.7 \mathrm{pg} /$ $\mathrm{mL}$ (range 20.97-230.70 pg/mL) in patients with OSAS and $16.1 \mathrm{pg} / \mathrm{mL}$ (range $10.1-22.9 \mathrm{pg} / \mathrm{mL}$ ) in the control group $(p<0.005)$. Serum S100B protein level did not correlate with any studied variable ( $p>0.05$ for each correlation coefficient). Conclusions: Serum S100B protein level is increased in patients with OSAS and may be a useful biochemical marker in those patients.
\end{abstract}

\section{Streszczenie}

Wstęp i cel pracy: Celem pracy było podkreślenie znaczenia stężenia białka S100B w surowicy jako przydatnego wskaźnika biochemicznego u chorych na zespół obturacyjnego bezdechu podczas snu (obstructive sleep apnea syndrome - OSAS). Materiał i metody: W badaniu wzięło udział 43 chorych ze świeżo rozpoznanym OSAS [mediana wskaźnika bezdechów/spłyconych oddechów, AHI (epizody na godzinę): 37,5 (zakres: 11,3-137)] oraz 25 osób z AHI < 5 [mediana: 4,4 $(0,7-4,8)]$ stanowiących grupę kontrolną. W obu grupach zmierzono stężenie białka S100B w surowicy pobranej po wykonaniu polisomnografii i sprawdzono różnicę w tym zakresie między grupami. Ponadto w grupie chorych na OSAS określono korelację między stężeniem białka S100B w surowicy a wiekiem, wskaźnikiem masy ciała, AHI, średnim wysyceniem krwi tętniczej tlenem podczas snu, najmniejszym wysyceniem krwi tętniczej tlenem na zakończenie okresu bezdechu oraz czasem, w którym wysycenie krwi tętniczej tlenem wynosiło $<90 \%$.

Wyniki: Mediana stężenia białka S100B w surowicy wyniosła 133,7 pg/ml (zakres: 20,97-230,70 pg/ml) u chorych na OSAS oraz 16,1 pg/ml (zakres: 10,1-22,9 pg/ml) w grupie kontrolnej ( $p<0,005)$. Stężenie białka S100B w surowicy nie korelowało z żadną ocenianą zmienną ( $p>0,05$ dla każdego współczynnika korelacji).

Correspondence address: Serap Duru, MD, Clinic of Chest Disease, Dışkapı Yıldııım Beyazıt Training and Research Hospital, Ankara, Turkey, phone: +90312 5962776,fax:+903123186690,e-mail: akcalis@hotmail.com

Received: 26.11.2011; accepted: 30.04 .2012 
Key words: S100B protein, obstructive sleep apnea syndrome, marker.

\section{Introduction}

Obstructive sleep apnea syndrome (OSAS) is characterized by episodic apnea/hypopnea due to upper airway obstruction during sleep. This syndrome is usually associated with increased cardiovascular morbidity and mortality [1]. Patients are diagnosed with OSAS if the value of the apnea-hypopnea index (AHI), obtained through polysomnography (PSG), exceeds 5 . The prevalence of OSAS is approximately $2 \%$ in women and $4 \%$ in men [2]. Upper respiratory tract obstruction in OSAS occurs due to a predisposition for pharyngeal collapse caused by a small lumen or increased extraluminal pressure. Upper respiratory tract obstruction is thought to be an effect, rather than a cause, which is triggered by a factor of central origin [3]. The pathophysiological mechanisms in OSAS include nocturnal intermittent hypoxia, apneas, increased sympathetic tone, inflammation, and oxidative stress.

Obstructive sleep apnea syndrome causes various problems, from simple snoring to serious pulmonary, cardiovascular, endocrine, and psychiatric disorders. Patients with OSAS experience daytime sleepiness, impaired memory, disordered cognitive functions, and difficulty in performing their daily activities.

In recent years, interest in the analysis of neurobiochemical markers, such as S100B protein, glial fibrillary acidic protein, and neuron-specific enolase, for various central nervous system diseases has been gradually increasing [4]. S100B protein is a member of the S100 family. The S100 family, which performs many intracellular and extracellular regulating activities, is a broad subgroup of calcium binding proteins [5]. The members of this protein family interact with many effector proteins, regulate enzyme activities, affect the structure of the cytoskeleton, and ensure cell growth, cell differentiation and calcium homeostasis. $\mathrm{S} 100 \mathrm{~B}$ protein is coded via the 22.3 locus of chromosome 21 [6]. S100B is produced principally by astrocytes and has autocrine and paracrine effects on glia, neurons and microglia [7].

In recent studies, a correlation was found between the size of the infarct resulting from ischemic brain damage and the serum S100B protein level $[8,9]$, and it is
Wnioski: Stężenie białka S100B w surowicy jest zwiększone u chorych na OSAS i może być przydatnym wskaźnikiem biochemicznym u tych pacjentów.

Słowa kluczowe: białko S100B, zespół obturacyjnego bezdechu podczas snu, znacznik.

possible to use protein S100B measurements to monitor stroke treatment [10]. Increased S100B levels in cases of hypoxia are similar to those noted in traumatic damage. In a few recent studies performed in OSAS patients, increased serum S100B protein levels were found $[11,12]$.

In the current study, the serum S100B protein levels of patients with OSAS were measured and compared with the control group. We also aimed to demonstrate the relationship between serum S100B protein levels and sleep-related variables such as AHI values, mean $\mathrm{O}_{2}$ saturation during sleep, minimum $\mathrm{O}_{2}$ saturation value at the end of the apnea and the time spent at an $\mathrm{O}_{2}$ saturation below $90 \%$ in patients with OSAS.

\section{Material and methods}

\section{Patients}

In total, 68 patients (26 women) who presented to the sleep outpatient clinic in the Chest Diseases Department of Diskapi Ylldırım Beyazıt Training and Research Hospital between January 2011 and July 2011 with complaints of snoring, witnessed apnea at night and excessive daytime sleepiness were enrolled in the study. Patients with comorbid diseases, acute infections, malignancies, recent myocardial infarction, recent surgery, chronic use of sleep-affecting drugs (such as hypnotics), alcohol intake, restless leg syndrome, sleep phase disorder, and/or periodic leg movements during sleep were excluded from the study.

The study was planned in compliance with the Helsinki Declaration and with the recommendations of our hospital's ethics committee. All patients signed a voluntary informed consent form before the study commenced.

\section{Methods}

Demographic data, smoking habits and alcohol consumption habits of the patients in the study were investigated. A detailed physical examination was performed in each patient, and height, body weight and neck cir- 
cumference measurements were taken. After the patients were assessed by an ear-nose-throat specialist, those found to have anatomical nasal and/or chin problems (such as septal deviation, conchal hypertrophy, or retromicrognathia) were excluded from the study. Apnea was defined as complete cessation of airflow for 10 seconds. The Epworth Sleepiness Scale (ESS) was applied to the patients to evaluate daytime sleepiness. The validity of the Turkish version of the scale was previously documented [13].

The body mass index (BMI) of each patient was calculated by dividing body weight in kilograms by the square of the patient's height in meters. To exclude additional diseases, levels of plasma aspartate and alanine aminotransferase, bilirubin, urea, creatinine, total $\mathrm{T} 3$ and T4, thyroid-stimulating hormone, total cholesterol, triglyceride, high density lipoprotein, low density lipoprotein, hemogram, and C-reactive protein, as well as erythrocyte sedimentation rate, were examined using commercial kits and standard laboratory tests. In addition, respiratory function tests, blood gas analysis, electrocardiography, and chest X-rays were assessed. Respiratory function tests were performed in the hospital's respiratory laboratory according to American Thoracic Society (ATS) criteria and using a Jaeger spirometer. Forced expiratory volume in one second $\left(\mathrm{FEV}_{1}\right)$ and forced vital capacity (FVC) were measured at least three times and the optimal ratios $\left(\mathrm{FEV}_{1} / \mathrm{FVC}, \%\right)$ were recorded. All patients were hospitalized in our sleep clinic for one night to undergo PSG. Fasting venous blood samples of $10 \mathrm{cc}$ were taken from patients between 7:00 a.m. and 8:00 a.m. after PSG. Then, the blood samples were centrifuged at $5000 \mathrm{rpm}$ for 10 minutes. Separated serum samples were stored at $-70^{\circ} \mathrm{C}$. Serum $\mathrm{S} 100 \mathrm{~B}$ protein levels were measured using the ELISA (Dia Metra, Italy) kit.

Before PSG, a standard questionnaire, including ESS, was administered. Following the physical examination, patients, who were tested for respiratory functions, underwent a sleep technician attended polysomnographic examination for a whole night using a 64-channel Comumedics ${ }^{\circledR}$ E-series polysomnography device (for 6-8 hours). Six-channel electroencephalogram (EEG; C3-M2, C4M1, F1-M2, O1-M2, O2-M1, F2-M1), electrooculogram (EOG), electromyogram (EMG, submental and tibialis muscles), electrocardiogram (EKG), oronasal air flow (cannula and thermistor), abdominal and thoracic respiratory movements, snoring (tracheal microphone), body positions, and pulse oximeter (fingertip) parameters were evaluated using the Profusion software program version 3. Scoring of sleep and respiratory events was per- formed (e.g., apnea, hypopnea, and desaturation) according to American Academy of Sleep Medicine (AASM) criteria. Sleep recordings with sleep efficacy of $69 \%$ or more were considered valid. Patients were divided into three groups based on AHI and analysis was performed within each group as follows: normal (AHI $<5 ; n=25$ ), mild OSAS (AHI between 5 and $15 ; n=13$ ), moderate OSAS (AHI between 15 and $30 ; n=21$ ), or severe OSAS (AHI $>30 ; n=9)$.

\section{Statistical analysis}

For normally distributed data, average measurements were calculated as mean \pm standard deviation (SD); median was used for non-normally distributed variables. Differences between ages and BMIs of the control group and the patient group were normally distributed and investigated using the t-test for independent samples, while differences in serum S100B protein levels, AHI values, mean $\mathrm{O}_{2}$ saturation during sleep, minimum $\mathrm{O}_{2}$ saturation value at the end of the apnea and the time spent at an $\mathrm{O}_{2}$ saturation below $90 \%$, which were not normally distributed, were investigated using the Mann-Whitney $U$-test. A difference was considered statistically significant if a $p$-value was less than 0.05 in the two-sided statistical testing. The relationship between serum S100B protein level and other OSAS-related continuous variables was investigated using the Spearman correlation analysis. Correlations with $p$-values less than 0.05 were interpreted as significant.

\section{Results}

Demographic and PSG data for the 68 patients monitored overnight at our hospital are shown in Table 1.

Serum S100B concentration was significantly greater in patients with OSAS than in controls $(p<0.005)$ (Table 1).

The relationships between serum S100B protein level and the other OSAS patient variables are shown in Table 2. Serum S100B protein level did not correlate with age, $\mathrm{BMI}, \mathrm{AHI}$, mean $\mathrm{O}_{2}$ saturation during sleep, minimum $\mathrm{O}_{2}$ saturation value at the end of the apnea or the time spent at an $\mathrm{O}_{2}$ saturation below $90 \%$.

\section{Discussion}

Up to now, there have been few studies investigating serum S100B protein levels of patients with OSAS. 
Table 1. Demographic, polysomnographic and laboratory data of studied patients and controls

\begin{tabular}{|c|c|c|c|}
\hline Variables & OSAS $(n=43)$ & Controls $(n=25)$ & $P$-value \\
\hline Age [years]; mean (SD) & $47.23(6.24)$ & $43.76(8.82)$ & $>0.05$ \\
\hline Sex $[$ female/male]; $n$ & $18 / 25$ & $8 / 17$ & $>0.05$ \\
\hline Cigarette smoking [pack/year], (+/-) & $10 / 33$ & $5 / 20$ & $>0.05$ \\
\hline Body mass index $\left[\mathrm{kg} / \mathrm{m}^{2}\right]$, median (range) & $29.6(24.4-46.1)$ & $27(21.5-33.9)$ & $>0.05$ \\
\hline Apnea-hypopnea index [events/hour]; median (range) & $37.5(11.3-137)$ & $4.4(0.7-4.8)$ & 0.000 \\
\hline Epworth Sleepiness Scale; mean (SD), range & $10.8(5.9), 8-11$ & $9.2(5.1), 8-10$ & $>0.05$ \\
\hline Mean $\mathrm{O}_{2}$ saturation (\%) during sleep; median (range) & $85(67-89)$ & $94(92-96)$ & 0.000 \\
\hline Minimum $\mathrm{O}_{2}$ saturation value (\%) at the end of the apneas; median (range) & $69.35(67-72)$ & $92(92-94)$ & 0.000 \\
\hline Time spent at $\mathrm{O}_{2}$ saturation below $90 \%$ [minutes]; median (range) & $141.7(39.3-337.5)$ & 0 & 0.000 \\
\hline \multicolumn{4}{|l|}{ Serum S100B protein level $[\mathrm{pg} / \mathrm{mL}]$, median (range): } \\
\hline All patients/controls & $133.77(20.9-230.7)$ & $16.1(10.1-22.9)$ & 0.000 \\
\hline Mild OSAS $(n=13)$ & $135.6(20.9-214.6)$ & & \\
\hline Moderate OSAS $(n=21)$ & $145.53(24.67-221.56)$ & & \\
\hline Severe OSAS $(n=9)$ & $147.34(29.78-230.7)$ & & \\
\hline
\end{tabular}

OSAS - obstructive sleep apnea syndrome; SD - standard deviation

In this study, a significant difference was observed between serum S100B protein levels of subjects in the control group and OSAS patients with no concomitant disease which might cause cerebral damage $(p<0.005)$. However, no significant correlation was found between serum S100B protein level and OSAS related variables such as $\mathrm{AHI}$, mean $\mathrm{O}_{2}$ saturation during sleep, minimum $\mathrm{O}_{2}$ saturation value at the end of the apnea, the time spent at an $\mathrm{O}_{2}$ saturation below $90 \%$ or patient characteristics, like age and BMI.

In recent years, S100B protein has been largely focused on as a biochemical marker of cerebral disorders. Increased serum S100B protein level may reflect either glial damage or astrocytic reactions to neural injury [14]. Serum S100B protein levels increase after trauma and after stroke [15]. In previous studies, serum S100B protein level was associated with severity of trau$\mathrm{ma}$ and disease prognosis [16]. In hypoxia following cardiac arrest, serum S100B protein level has been correlated with clinical manifestation and the stage of coma $[17,18]$.

In OSAS, recurrent apnea-hypopnea episodes lead to desaturation and intermittent hypoxia with deteriorating oxygenation. Therefore, cerebral damage may occur following hypoxia. Recent studies on serum S100B protein levels of patients with OSAS have generated different results. Silva et al. [11] found that
Table 2. Correlation between serum S100B protein level and sleep-related variables in patients with obstructive sleep apnea syndrome $(r$ - Spearman correlation coefficient)

\begin{tabular}{|lcc|}
\hline Variables & $\begin{array}{c}\text { Serum S100B protein } \\
\text { level } \mathbf{~ p g} / \mathbf{m L} \text { ) }\end{array}$ \\
\cline { 2 - 3 } & $\boldsymbol{r}$ & $\mathbf{p}$-value \\
\hline Age [years] & -0.004 & 0.777 \\
\hline Body mass index $\left[\mathrm{kg} / \mathrm{m}^{2}\right]$ & -0.166 & 0.287 \\
\hline Apnea-hypopnea index [events/hour] & 0.150 & 0.333 \\
\hline Mean $\mathrm{O}_{2}$ saturation (\%) during sleep & -0.002 & 0.989 \\
\hline $\begin{array}{l}\text { Minimum } \mathrm{O}_{2} \text { saturation value (\%) } \\
\text { at the end of the apneas }\end{array}$ & -0.262 & 0.089 \\
\hline $\begin{array}{l}\text { Time spent at } \mathrm{O}_{2} \text { saturation below 90\% } \\
\text { [minutes] }\end{array}$ & 0.113 & 0.476 \\
\hline
\end{tabular}

S100B levels were higher after PSG than before PSG. Braga et al. [12] reported a significantly higher serum $\mathrm{S} 100 \mathrm{~B}$ protein level in patients with OSAS compared to the control group.

In another study, serum S100B protein level in OSAS patients was slightly increased in only two patients with severe OSAS [19]. On the other hand, among 60 male patients with OSAS, a significant difference was found between morning and evening serum S100B protein levels in patients with moderate OSAS, but no such 
difference was observed for patients with severe OSAS. In addition, serum S100B protein level correlated negatively with AHI values and oxygen desaturation index, and positively with basal saturation and average minimal oxygen saturation [20].

In both traumatic and hypoxic cases, degeneration may occur in astrocytes. In such cases, serum S100B protein level increases. In many clinical trials, increased serum S100B protein levels in the early post-stroke period have been associated with clinical and/or functional outcomes [21]. In prior studies [22,23], cerebrovascular and neuropsychiatric diseases caused increased serum S100B protein release from astrocytes. The other studies showed that the patients with OSAS had additional diseases. So the increases of serum S100B protein level in patients in other studies suggest that OSAS can be controlled by a complex alarm network. In this study, we determined that serum S100B protein level was increased in OSAS patients with no additional disease or morbid obesity. We propose that OSAS may increase release of $\mathrm{S} 100 \mathrm{~B}$ protein in astrocytes.

OSAS is characterized by disordered respiration patterns during sleep. In OSAS, repetitive episodes of apnea cause increased sympathetic nerve activity, increased surges in arterial blood pressure, oxidative stress, hypoxia and hypercapnia [24]. To date, the mechanism of action of S100B protein remains unclear. One could assume that those cerebral changes which occur during sleep may increase the serum S100B protein level. Different diseases produce different S100B protein levels, suggesting that it has different effects on the various parts of the body depending on the disease. For example, in nanomolar concentrations it stimulates neuron growth and protects neurons against oxidative stress. If it reaches the micromolar level in the extracellular region of the brain, it stimulates inflammation, induces apoptosis and causes neuron damage [6].

Serum S100B protein concentration does not correlate with the level of that protein in the brain and cerebrospinal fluid [25], because S100B protein cannot pass freely through the blood-brain barrier. For the reasons explained above, our study may not reflect a relation between serum S100B protein and OSAS-related variables.

OSAS may be associated with cardiovascular and metabolic diseases and conditions such as hypertension, diabetes mellitus, obesity, coronary artery disease, stroke, and heart failure. Therefore, OSAS is an important health problem, and future clinical use of the serum S100B protein level may be helpful in the evaluation of OSAS. We believe that the results of our study will contribute to the literature since only a few studies have been performed on serum S100B protein levels in patients with OSAS. The major limiting factor in our study was that it is difficult to find patients having OSAS without any additional diseases.

\section{Conclusion}

Serum S100B protein levels may increase in patients with OSAS, suggesting an astrocyte reaction in patients with OSAS. S100B protein may therefore be a useful biochemical marker in OSAS patients.

\section{Disclosure}

Authors report no conflict of interest.

\section{References}

1. Peker Y., Hedner J., Kraiczi H., et al. Respiratory disturbance index: an independent predictor of mortality in coronary artery disease. Am J Respir Crit Care Med 2000; 162: 81-86.

2. Young T., Palta M., Dempsey J., et al. The occurrence of sleepdisordered breathing among middle-aged adults. $N$ Engl J Med 1993; 328: 1230-1235.

3. Richter D.W., Spyer K.M. Studying rhytmogenesis of breathing: comparison of in vivo and in vitro models. Trends Neurosci 2001; 24: 464-472.

4. Bloomfield S.M., McKinney J., Smith J., et al. Reliability of s100B in predicting severity of central nervous system injury. Neurocrit Care 2007; 6: 121-138.

5. Donato R. Intracellular and extracellular roles of S100 proteins. Microsc Res Tech 2003; 60: 540-551.

6. Rothermundt M., Petres M., Prehn J.H., et al. S100B in brain damage and neurodegeneration. Microsc Res Tech 2003; 60: 614-632.

7. Adami C., Sorci G., Blasi E., et al. S100B expression in and effects on microglia. Glia 2001; 33: 131-142.

8. Jönsson H. S100B and cardiac surgery: possibilities and limitations. Restor Neurol Neurosci 2003; 21: 151-157.

9. Asano T., Mori T., Shimodo T., et al. Arundic acid (ONO-2506) ameliorates delayed ischemic brain damage by preventing astrocytic overproduction of S100B. Curr Drug Targets CNS Neurol Disord 2005; 4: 127-142.

10. Węglewski A., Ryglewicz D., Mular A., et al. Changes of protein S100B serum concentration during ischemic and hemorrhagic stroke in relation to the volume of stroke lesion. Neurol Neurochir Pol 2005; 39: 310-317.

11. Silva L.G., Mottin C.C., Souza D.O., et al. Serum S100B but not NSE levels are increased in morbidly obese individuals affected by obstructive sleep apnea-hypopnea syndrome. Obes Surg 2008; 18: 993-999. 
12. Braga C.W., Martinez D., Chukchi S., et al. S100B and NSE serum levels in obstructive sleep apnea syndrome. Sleep Med 2006; 7: 431-435.

13. Izci B., Ardic S., Hikmet F, et al. Reliability and validity studies of the Turkish version of the Epworth Sleepiness Scale. Sleep Breath 2008; 12: 161-168.

14. Herrmann M., Vos P., Wunderlich M.T., et al. Release of glial tissue-specific proteins after acute stroke: a comparative analysis of serum concentrations of protein S-100B and glial fibrillary acidic protein. Stroke 2000; 31:2670-2677.

15. Ettinger A., Laumark A.B., Ostroff R.M., et al. A new optical immunoassay for detection of S-100B protein in whole blood. Ann Thorac Surg 1999; 68: 2196-2201.

16. Raabe A., Kopetsch O., Woszczyk A., et al. Serum S-100B protein as a molecular marker in severe traumatic brain injury. Restor Neurol Neurosci 2003; 21: 159-169.

17. Böttiger B.W., Möbes S., Glätzer R., et al. Astroglial protein $\mathrm{S} 100$ is an early and sensitive marker of hypoxic brain damage and outcome after cardiac arrest in humans. Circulation 2001; 103: 2694-2698.

18. Mussack T., Biberthaler P., Kanz K.G., et al. S100b, sE-selectin and $\mathrm{sP}$-selectin for evaluation of hypoxic brain damage in patients after cardiopulmonary resuscitation pilot study. World J Surg 2001; 25: 539-543.

19. Jordan W., Hagedohm J., Wiltfang J., et al. Biochemical markers of cerebrovascular injury in sleep apnoea syndrome. Eur Respir $J$ 2002; 20: 158-164.

20. Sonka K., Kelemen J., Kemlink D., et al. Evening and morning plasma levels of protein S100B in patients with obstructive sleep apnea. Neuro Endocrinol Lett 2007; 28: 575-579.

21. Bertsch T, Casarin W., Kretschmar M., et al. Protein S100B a serum marker for ischemic and infectious injury of cerebral tissue. Clin Chem Lab Med 2001; 39: 319-323.

22. Gale S.D., Hopkins R.O. Effects of hypoxia on the brain: neuroimaging and neuropsychological findings following carbon monoxide poisoning and obstructive sleep apnea. J Int Neuropsychol Soc 2004; 10: 60-71

23. Hu J., Ferreira A., Van Eldik L.J. S100beta induces neuronal cell death through nitric oxide release from astrocytes. $J$ Neurochem 1997; 69: 2294-2301.

24. Dursunoğlu N., Dursunoğlu D. Obstructive sleep apnea syndrome, endothelial dysfunction and coronary atherosclerosis. Tuber Toraks 2005; 53: 299-306.

25. Kleindienst A., Ross Bullock M. A critical analysis of the role of the neurotrophic protein S100B in acute brain injury. J Neurotrauma 2006; 23: 1185-1200. 